\title{
CONTROLE E TRANSGRESSÃO DAS FRONTEIRAS NO SUL DO BRASIL IMPÉRIO: A CONSTRUÇÃO DO ESTADO PELAS MARGENS
}

\author{
Mariana Flores da Cunha Thompson Flores \\ Departamento de História da Universidade Federal de Santa Maria (UFSM-RS) \\ (Santa Maria, RS, Brasil) \\ ORCID: https://orcid.org/0000-0002-1520-3113 \\ mariclio@yahoo.com.br
}

O presente artigo parte de um agradecimento a Juan Carlos Garavaglia através da incorporação de questões desenvolvidas por ele às reflexões que têm sido centrais em minhas investigações, tais como as características de instabilidade e conflito inerentes aos espaços de fronteira e o olhar acurado para as diferentes lógicas de funcionamento da justiça para ricos e pobres. Contudo, compreender a fronteira como elemento de construção do Estado (o que devo ao periodo que estive ligada ao grupo State Building in Latin America), percebendo a burocracia específica -instituições de repressão e controle fiscal-foram fundamentais em minhas reflexões sobre a construção do estado nos espaços limítrofes. É sobre o funcionamento da Alfandega de Uruguaiana, na fronteira sul do Império do Brasil, na segunda metade do século XIX, que este artigo se dedica.

PalavRas-Chave: Fronteira. Construção do estado. Contrabando. Controle fiscal.

\section{Control and TRANSGRESSION OF Borders in the SOUTH OF BRAZIL EMPIRE: the CONSTRUCTION OF THE STATE FROM THE LIMITS}

This article wants to thank to Juan Carlos Garavaglia for the questions developed by bim that were incorporated in my investigations, such as the characteristics of instability and conflict inherent in the frontier spaces and the accurate look at the different justice logics for rich and poor. However, understanding the notion of frontier as a state-building element (which I owe to the period I was linked to the group State Building in Latin America), realizing the specific bureaucracy -institutions of repression and tax control-were central to my reflections on the construction of the state in bordering spaces. It is about the functio- 
ning of the Uruguaiana Customs, on the southern border of the Brazilian Empire, in the second half of the 19th century, that this article is dedicated.

KEYWORDS: Border. State building. Smuggling. Tax control.

Como ponto de partida, considerando ser essa uma publicação em um dossiê destinado a homenagear o estimado Professor Juan Carlos Garavaglia, mais do que nunca se mostra pertinente a oportunidade que tenho de tornar explícito o quanto o aprendizado que tive com ele ${ }^{1}$ foi fundamental para que eu pudesse melhor compreender meus objetos de pesquisa, quais sejam: criminalidade e fronteira.

Antes mesmo da relação de trabalho que estabelecemos, as leituras de seus trabalhos já me inspiravam de várias formas. A ideia de que os espaços de fronteira têm por característica constitutiva o fato de serem instáveis, conflitivos e violentos, que está presente na obra «Poder, conflicto y relaciones sociales», quando menciona a «realidad violenta de la frontera», ou a «situación fronteriza inestable y violenta», ${ }^{2}$ ao referir-se aos elevados índices de criminalidade da região sul de Buenos Aires se comparados com os da região norte, em meados do século XIX, em função da condição fronteiriça dessa região sul, serviu de base para toda a argumentação que desenvolvi em minha tese. ${ }^{3}$ Em termos gerais, o que pude detectar foi que a criminalidade estava intimamente ligada à vida da fronteira, e que os crimes inseridos nesse espaço tendiam a assumir características particulares. Os crimes ocorridos em uma fronteira apresentam certa especificidade em função de estarem contidos nesse espaço dinâmico, que oferece um ambiente que os diferencia de um mesmo tipo de crime praticado em outros lugares, que não uma zona de fronteira. A dinâmica diferenciada dos espaços limítrofes se dá em função de que oferecem margens de ação e negociação aos sujeitos que lá atuavam através de redes sociais e familiares transfronteiriças, combinando com a diversificação das atividades econômicas e valendose das brechas existentes entre as soberanias justapostas, a fim de se manterem e reproduzirem nesse espaço complexo. Para tanto, a situação de fronteira era um elemento a ser levado em conta nessas estratégias, sendo manejada pelos atores sociais de acordo com os contextos dados.

Além da característica instável e conflitiva própria aos espaços de fronteira, outra noção fundamental legada pelos trabalhos do professor Garavaglia, que me foi de grande valia para a compreensão dos meus objetos, tem a ver com concepção de justiça implica-

1. Agradezco al equipo del proyecto State Building in Latin America, que me acogieron con tanto cariño en Barcelona, y con quienes he podido compartir la experiencia de investigación más encantadora que he vivido. ¡Gracias al Profesor Juan Carlos Garavaglia, Claudia Contente, y a los chicos del proyecto (Mario, Evangelina, Juan Carlos, Pablo, Pilar, Elvira y Viviana)!

2. Garavaglia, Juan Carlos, Poder, conflicto y relaciones sociales: el Rio de la Plata, XVIII-XIX, Rosario, Homo Sapiens Ediciones, 1999, p. 72.

3. Thompson Flores, Mariana F. da C., Crimes de fronteira: a criminalidade na fronteira meridional do Brasil (1845-1889), Porto Alegre, EdiPUCRS, 2014. 
da na análise desses crimes. Se de um lado apontei a vinculação superficial entre processos crimes e a sobrerrepresentação de indivíduos marginais, até porque a realidade documental da qual dispunha revelava uma sociedade fronteiriça complexa, na qual tanto ricos como pobres apareciam envolvidos em atividades ilícitas utilizando-se do recurso da fronteira em suas estratégias sociais, de acordo com seus respectivos lugares sociais, ao mesmo tempo ficava patente que os processos também deixavam transparecer que «ricos y pobres no parecen formar parte del mismo universo legal», ${ }^{4}$ no sentido de que determinadas sentenças e tolerâncias podiam ser aplicadas a certas camadas sociais e negadas a outras.

Contudo, sem dúvida, a contribuição mais substancial se deu na forma como passei a compreender a fronteira como elemento de construção do Estado, o que muito se deve ao período que pude participar como investigadora associada ao grupo State Building in Latin America, coordenado pelo Professor Garavaglia.

Ao considerar a fronteira por sua natureza política, de delimitação territorial, se está tratando de um marco, de um elemento basilar, da configuração dos Estados Nacionais modernos. Nesse sentido, ao perceber que o Estado se faz presente nesses espaços através de uma burocracia específica — como leis, guardas de fronteira, alfândegas- questões como a estruturação de órgãos burocráticos de repressão e controle fazendário passaram a compor minhas preocupações de investigação no que se referia à construção do estado nacional nos espaços limítrofes.

Diversos estudos têm apontado para a íntima relação existente entre o processo de construção dos Estados modernos e os contextos de guerra e formação dos mecanismos de justiça e de fiscalidade.

O ponto de partida parece ter ocorrido com a publicação de um artigo de autoria de Joseph Schumpeter, em 1954, que marcou toda uma linha de pesquisas assinalando a relevância da história fiscal como ponto de convergência entre história, economia e sociologia, bem como, que a fiscalidade era uma via privilegiada para a análise da formação dos Estados, pois permite pensar a construção das instâncias políticas em relação aos poderes locais considerando as tensões que gera e a constituição de instrumentos de poder específicos. ${ }^{5}$

A partir da década de 1970, apareceram as contribuições teóricas mais importantes sob essa abordagem, as quais acabaram delimitando o conceito do «estado militar fiscal», o qual acabou adquirindo uma hegemonia explicativa considerável nos marcos da historiografia européia. Segundo Josep M. Delgado Ribas,

parece existir un cierto consenso entre la historiografía que ha teorizado sobre los orígenes del Estado en la Europa Moderna en que existe una relación de causalidad entre el desarrollo de un aparato fiscal centralizado que facilitara la captación de recursos para financiar las guerras

4. Garavaglia, Juan Carlos, Poder, conflicto y..., cit., pp. 31-32.

5. Schumpeter, Joseph, The crises of the tax state. In: International Economic Papers, N. 4, New York, Macmillan, 1954. 
y el nacimiento de una organización estatal compleja, que tendió a asumir progresivamente el monopolio en ejercicio de la coacción sobre unos territorios cada vez más extensos, que acabarían conformando los estados nacionales. ${ }^{6}$

Pode-se dizer que dois dos autores responsáveis pela formulação desses conceitos na historiografia europeia foram Charles Tilly e John Brewer. ${ }^{8}$

Charles Tilly, cunhou o conceito do «círculo de coerção e extração», no qual a interação entre fiscalidade e a guerra constituem uma das formas mais ricas de aproximar-se do processo construção dos estados modernos europeus, evidenciando o papel que as atividades extrativas e repressivas do Estado associadas desempenharam na centralização do poder, além de terem funcionado como desencadeadoras de tensões entre setores da sociedade e o centro de poder. Esse processo é explicado pelo autor através de uma relação na qual um governante que adquiriu poder militar poderá usá-lo para obter mais recursos para pagar mais soldados e adquirir mais tecnologia que serão aplicados para conseguir mais rendas, em um processo que se conclui no controle de um determinado território. ${ }^{9}$ Ou seja, o aumento dos gastos bélicos e de repressão carregam em si a necessidade de incrementar o sistema burocrático de arrecadação e controle a fim de manter e acompanhar esse crescimento. ${ }^{10}$

John Brewer, por sua vez, demonstra que o domínio alcançado pela Inglaterra, nos séculos XVII e XVIII, esteve diretamente relacionado com a maior eficiência de seu sistema fiscal e de sua capacidade militar para extrair recursos de seus súditos. Assim, o gasto bélico repercutiu em formas de taxação cada vez mais eficientes, capazes de alimentar a própria «máquina de guerra», conformando as bases do Estado moderno. ${ }^{11}$

Para o contexto americano, é incontornável citar o trabalho de Túlio Halperín Donghi ${ }^{12}$ que demonstrou a conexão direta entre a ordem fiscal e o contexto bélico, iniciado em 1806 e que se estendeu até meados do século, na formação dos poderes locais

6. Delgado Ribas, Josep M., «Construir el Estado, destruir la Nación. Las reformas fiscales de los primeros Borbones e el colapso del sistema de equilibrios en el Imperio español (1714-1796)», Illes i Imperis, Estudis d'història de les societats en el món colonial i postcolonial, núm. 13, 2010, pp. 63-85.

7. Tilly, Charles, «Reflections on the history of European state-making», en Tilly, Charles (ed.), The formation of national states in Western Europe, Princeton, Princeton University Press, 1975;Tilly, Charles, Coerção, capital e Estados europeus. São Paulo, EDUSP, 1996. Brewer, John. The sinews of Power. War, Money and English State, 1668-1783, London, Routledge, 1994 [1 ed. 1989].

8. Brewer, John. The sinews of..., cit.

9. Ver: Tilly, Charles, Reflections on the ..., cit.; Tilly, Charles, Coerção, capital e..., cit.

10. Garavaglia, Juan Carlos, «Algunos aspectos preliminares acerca de la «transición fiscal», en America Latina, 1800-1850», Illes i Imperis. Estudis d'història de les societats en el món colonial i postcolonial, núm. 13, 2010, p. 177.

11. O autor Michael J. Braddick discorda da tese de John Brewer no sentido de que compreende que a chave explicativa para o êxito arrecadador da Inglaterra no século XVII deveu-se mais a maior legitimidade e menor arbitrariedade, do que ao caráter mais agressivo impresso por J. Brewer à arrecadação. Braddick, Michael J., «Fiscal transformation and political compliance: England, 1550-1700», Illes i Imperis, Estudis d'història de les societats en el món colonial i postcolonial, núm. 13, 2010, pp. 21-37.

12. Halperín Donghi, Túlio. Guerra y finanzas en los orígenes del Estado Argentino (1791-1850), Buenos Aires, Prometeo Libros, 2005 [1 ed. 1982]. 
da região do Rio da Prata e na concorrência destes para a construção dos respectivos Estados.

Tais autores compartilham o conceito, o qual se convencionou chamar, de «estado militar fiscal». Sua ideia central consiste em compreender que o Estado moderno se constituiu a partir da configuração de um sistema fiscal que atuava para captar recursos cuja finalidade era financiar as guerras. A guerra e a arrecadação de impostos, portanto, atuaram como forças centrípetas do processo de consolidação do Estado. Muito antes de qualquer outra forma de o Estado fazer-se sentir a todos seus súditos/cidadãos, a arrecadação fiscal e o monopólio da força (desde dentro e para fora do território) fizeram-se presentes em todos os lugares, em cada recôndito do território, embora, a princípio, muito menos através da atuação de um sistema centralizado de funcionários e soldados, mas através de alianças com os poderes locais. Nesse sentido, não foi o Estado que construiu o sistema de arrecadação moderno, mas o Estado se construiu no ritmo que dava forma a procedimentos e regras que conduziram a organização da fiscalidade. ${ }^{13}$

No que se refere à historiografia brasileira, Wilma Peres Costa tem sido uma referência nesses estudos que protagonizam a formação dos sistemas fiscal e militar na construção do estado. ${ }^{14}$ Sua abordagem compreende que o Estado se constrói no Brasil a partir da crise do Império português e fundamentado na herança colonial, sobretudo, levando-se em consideração a questão da instalação da corte portuguesa no Brasil a partir de 1808. Contudo, mesmo sendo inegável a continuidade institucional que se verifica no Brasil, sob vários aspectos após a independência, a autora demonstra que as análises pautadas na fiscalidade são capazes de apontar rupturas e transformações que puderam decorrer nos mais variados conflitos e acomodações sociais rumo à consolidação do Estado.

Além deste, trabalhos como o de Luciano Figueiredo ${ }^{15}$ e Keneth Maxwell ${ }^{16}$ também $^{2}$ têm entendido a fiscalidade, na interpretação da história do Estado no Brasil, como o exercício do poder de extração de recursos sobre a população de um território que tende a gerar conflitos. A partir de marcos cronológicos emblemáticos, como as reformas pombalinas, a transferência da Corte portuguesa para o Brasil e a independência, esses auto-

13. Fradera, Josep Maria, «Presentación», Illes i Imperis. Estudis d'història de les societats en el món colonial i postcolonial, núm. 13, 2010, p. 9.

14. Costa, Wilma Peres, «Do domínio à nação: os impasses da fiscalidade no processo de Independência», Jancsó, István (ed.), Brasil: formação do estado e da nação, São Paulo, HUCITEC, 1996, 2003; Costa, Wilma Peres, «A Independência na historiografia brasileira», Jancsó, István (ed.), Independência: história e historiografia, São Paulo, Hucitec/FAPESP, 2005; Costa, Wilma Peres, «A fiscalidade e seu avesso: centro e províncias na constituição da estrutura fiscal brasileira na primeira metade do século XIX», Chaves, Cláudia M. das G. Silveira, Marco A. Território, conflito e identidade, Belo Horizonte, Argvmentvum, Brasília, CAPES, 2007, pp. 127 148; Costa, Wilma Peres e Márcia Eckert Miranda, «Entre os senhores e o Império: transformações fiscais na formação do Estado brasileiro, 1808-1840», Illes i Imperis. Estudis d'història de les societats en el món colonial i postcolonial, núm. 13, 2010, pp. 87-115.

15. Figueiredo, Luciano Raposo de Almeida, Revoltas, fiscalidade e identidade colonial na América portuguesa - Rio de Janeiro, Babia e Minas Gerais, 1540-1761, Faculdade de Filosofia, Letras e Ciências Humanas, Universidade de São Paulo, São Paulo, 1996, Tese de Doutorado.

16. Maxwell, Kenneth R., A devassa da devassa: a Inconfidencia Mineira: Brasil-Portugal-1750-1808, 2. ed. Rio de Janeiro, Paz e Terra, 1978. 
res demonstram que esses momentos constituíram pontos de inflexão marcantes no desenvolvimento do sistema fiscal, os quais se manifestaram de distintas formas nas diferentes regiões do território.

Para o contexto especificamente rio-grandense, esse modelo identificado para casos clássicos europeus, nos quais a interação entre guerra e fiscalidade incorreu em um movimento que concentrou recursos nas mãos do Estado aumentando sua capacidade de arrecadar tributos através do aperfeiçoamento da administração, da fiscalização e da ampliação do aparato coercitivo, não se aplica completamente. Conforme Márcia Eckert Miranda, ${ }^{17}$ no Rio Grande do Sul a subvenção privada dos recursos para a guerra, providas, no caso, pelos estancieiros locais, agiu no sentido de garantir autonomia a esses poderes locais dispersando o poder, em lugar de concentrá-lo nas mãos do Estado.

Para o contexto ora analisado no âmbito do presente trabalho, os debates historiográficos acima mencionados foram de grande valia a fim de melhor compreender de que formas o Estado se fazia sentir nos limites de seu território. Dessa maneira, ao sabermos que o Estado se estende de forma específica para suas franjas e continuamente se institui e reitera naqueles espaços, ${ }^{18}$ podemos começar a refletir sobre as instituições de governo na fronteira e no papel que desempenham no processo de construção do Estado. Além disso, quando se aborda a criminalidade na fronteira, se está analisando uma forma de transgressão a esse espaço, que constitui o limite do território do Estado, e, por conseguinte, um conflito, mais ou menos explícito, com o poder instituído.

Rui Cunha Martins, ${ }^{19}$ ao destacar o paradoxo fim/início da fronteira, chama atenção para o fato de que, ao delimitar, a fronteira está naturalmente apontando o que lhe é externo, mas, sobretudo, está explicitando o «invólucro que ela delimita», ${ }^{20}$ que é «a entidade patrocinadora da ativação dos limites». ${ }^{21}$ Ao delimitar, portanto, a fronteira designa sua referência, o alcance de seu centro de poder. Nesse sentido, a fronteira não é o contrário do centro, mas sua reserva, ou sua outra natureza.

A fronteira é, portanto, a tentativa permanente de sinalizar uma sede. Diz-se «tentativa permanente de sinalizar» porque o fato de estar em constante contato com outra soberania requer de seu autor (aquele que a fronteira designa/referencia) a tarefa continuada

17. Miranda, Márcia Eckert, A estalagem e o Império: crise do Antigo Regime, fiscalidade e fronteira na Província de São Pedro (1808-1831), Campinas-UNICAMP, 2006, Tese de Doutorado; Miranda, Márcia Eckert, «Fiscalidade e Guerra: o Rio Grande do Sul e o Brasil na Guerra Cisplatina», Anais do IX Encontro Estadual de História. Vestígios do Passado: a História e suas fontes, ANPUHRS, 2008; Costa, Wilma Peres e Márcia Eckert Miranda, «Entre os senhores e...», cit.

18. Para Rui Cunha Martins, o Estado torna-se «facto notório» através do estabelecimento de marcos fronteiriços e das cerimônias que os envolvem (p. 113), pelo exercício das funções burocráticas do Estado levadas a cabo pelos poderes locais que se mostram, surpreendentemente, conservadores e não tendem a mostrar grande desalinho com o centro, já que acabam sendo os grandes beneficiários dos estímulos econômicos proporcionados pela fronteira (p. 35). Martins, Rui Cunha, O método da fronteira: radiografia histórica de um dispositivo contemporâneo (Matrizes Ibéricas e Americanas), Coimbra, Edições Almedina, 2008.

19. Ibidem, pp. 112-116.

20. Ibidem, p. 112.

21. Ibidem, p. 113. 
de sua elucidação. Isso porque a fronteira carrega também um caráter instável, a contingência, que articula uma heterogeneidade de experiências e trajetórias e possibilita sua duplicação, sobreposição, apagamento, reposição. Dessa forma, trata-se de uma tarefa constante e para a qual não há previsão de conclusão, já que a fronteira referência nunca vai se impor à fronteira contingência; no entanto, o efeito da fronteira se dá na ação incessante de elucidação e não no resultado. Seu método de ação é progressivo, contínuo e sempre na tensão entre a designação da referência e a ação da contingência. ${ }^{22}$ Assim, a fronteira é um espaço periférico, mas não marginal, não foge ao controle do centro.

A ocorrência de crimes na fronteira corresponde ao fato de que esses espaços tendem a ser intrinsecamente instáveis, conflitivos e violentos e tais práticas, embora incorporadas ao cotidiano, não chegam a serem naturalizadas, banalizadas ou livres de conotação delitiva. Por isso, através da análise de crimes e da sua repressão é possível apreender uma faceta do processo de construção do estado nacional nas suas margens.

Para tanto, compreende-se os criminosos dessa fronteira não como membros de uma subcultura criminosa, nem tampouco como indivíduos atuando ideologicamente contra o avanço do estado e do capitalismo, mas como partilhantes de um substrato cultural em franco desajuste com certas normatizações advindas do estabelecimento da burocracia de estado, que cria leis que inventam crimes, mas que não se abatem sobre a sociedade como instrumentos explícitos de dominação de classe e sim como campos que permitem disputas e manejos.

A análise de crimes de fronteira passa pela prática de contrabando, a qual configura inquestionavelmente um crime de fronteira, já que se trata de um delito que só pode ocorrer onde há um limite político, ou por haver o atravessado em algum momento, mesmo que seja apreendido já muito longe da fronteira propriamente dita.

Os processos de apreensão de contrabando serviram para traçar como se caracterizava essa prática. O contrabando não constituía uma prática homogênea e, sendo assim, também não se trata de um crime restrito a populares. Na realidade, os contrabandistas, que de fato movimentavam o comércio da região, tratavam-se de grandes comerciantes que, não raro, ocupavam cargos públicos de destaque local. Concomitantemente havia os pequenos contrabandos que não dispunham de um aparato muito elaborado para sua execução e tinham finalidades diversas como revenda, consumo ou encomendas feitas entre conhecidos. Já os grandes carregamentos de contrabando buscavam abastecer as casas de comércio com produtos importados, por um custo bastante inferior ao que se tivessem passado regularmente pela Alfândega. Eles não eram simplesmente contrabandistas ou comerciantes, eram, justamente, «comerciantes-contrabandistas» ${ }^{23}$ e mobiliza-

22. Ibidem, p. 23.

23. Zacarias Moutoukias, referindo-se ao contrabando colonial no Rio da Prata no século XVII, alerta para a questão da «romantização» do contrabando. Mesmo se tratando de outro contexto diferente deste, seu alerta é bastante pertinente. Nas suas palavras, «[c]uando se aborda el tema del contrabando en la historia comercial de la Hispanoamérica colonial, es casi un acto reflejo imaginar a sus protagonistas organizados en bandas antes que en compañías o sociedades comerciales.» Moutoukias, Zacarias, Contrabando y control colonial en el siglo XVII: Buenos Aires, el Atlántico y el espacio peruano, Buenos Aires, Centro Editor de América Latina, 1987, p. 98. 
vam consideráveis recursos para a importação e atravessamento das mercadorias: homens armados e bem montados, carretas, embarcações, etc.

Entre as mercadorias que entravam, a maior incidência de importação era, sem dúvida, de fazendas de todos os tipos: das mais baratas e comuns às mais refinadas e dispendiosas. Os demais artigos, tais como utensílios domésticos (panelas, louças), bebidas, baralhos, chapéus, sapatos, cortes de roupas e objetos para senhoras como meias de seda e pregadores de cabelo, também iam de produtos acessíveis, ou comuns, aos mais refinados. A esses se somavam produtos de fabricação ou beneficiamento local, a maior parte derivados de produção primária, que se serviam das mesmas rotas pluviais. ${ }^{24}$

De maneira muito simples podemos dizer que o caminho percorrido pelas mercadorias importadas, que movimentavam o comércio na fronteira oeste do extremo sul do Império do Brasil, era entrar pelo Rio da Prata, pelos portos de Montevidéu ou Buenos Aires, e seguir por uma rota fluvial evidente rio acima até encontrar o Rio Uruguai e descarregar nos portos fluviais de Uruguaiana, Itaqui ou São Borja, ou ser descarregada um pouco antes e seguir por terra, em carretas, sendo introduzida pelas fronteiras secas com o Estado Oriental. Ao longo desse percurso, agregavam-se as produções locais nos entrepostos fluviais articulados a esse trajeto mercantil.

O levantamento dos processos crimes de apreensão de contrabando correspondentes aos municípios de Alegrete, Uruguaiana, Santana do Livramento e Quaraí, localizados na fronteira oeste do Brasil meridional, na segunda metade do século XIX, revelaram, no entanto, uma realidade documental mais restrita do que se esperava, mesmo sabendo-se da dimensão de sub-registro própria a esse tipo de fonte. Num período de 44 anos (18451889) apenas 45 registros de apreensão foram encontrados no acervo do Arquivo Público do Estado do Rio Grande do Sul, volume muito inferior ao que se supõe ter sido a dimensão da prática de contrabando naquela região. Aliados a esses registros de apreensão foram cruzados processos de responsabilidade, muito mais numerosos, que apontavam como réus funcionários públicos, frequentemente empregados na Alfândega de Uruguaiana e envolvidos com permissividades no controle da fiscalidade daquela repartição.

Desde o século XVIII os jesuítas já utilizavam a rota Rio Uruguai - Rio da Prata para enviar suas produções de erva-mate, mel e couros para Buenos Aires. ${ }^{25} \mathrm{O}$ comércio de produtos brasileiros para a Argentina e o Estado Oriental devia ser feito entrando oficialmente pelos portos de Buenos Aires e Montevidéu — sendo que o primeiro deteve por muito tempo o monopólio da navegação e do envio das mercadorias aos mercados compradores - ou por contrabando. Contudo, devido ao conflito existente entre as províncias argentinas e Buenos Aires por autonomia, já havia uma série de exceções, sobretudo por parte de Corrientes e Entre Rios, que permitiam o comércio direto com o Rio Grande do Sul. ${ }^{26}$

24. Medrano, Lília Inês Zanotti de, A livre navegação dos Rios Paraná e Uruguay: uma análise do comércio entre o Império Brasileiro e a Argentina (1852-1889), Tese de Doutorado - USP, São Paulo, 1989, p. 3.

25. Ibidem, p. 147.

26. Ibidem, pp. 149-150. 
A instalação da Alfândega em Uruguaiana, em 1849, se deu em função de que o destacado desenvolvimento comercial daquela vila demandava a instalação de um órgão permanente de fiscalização a fim de coibir o contrabando e arrecadar sobre as promissoras transações comerciais. ${ }^{27}$

Após o decreto da Livre Navegação dos rios da Bacia do Prata, em 1852, que assegurava livres de taxação as mercadorias introduzidas por Buenos Aires com destino aos países vizinhos, o comércio que já era vantajoso tornou-se ainda mais lucrativo, e o aumento do volume de transações foi vertiginoso..$^{28}$

Nesse contexto comercial, estudar a atuacão da Alfândega foi fundamental para a compreensão da dinâmica mercantil e, mesmo que pareça contraditório, revelou-se fundamental também para compreender o comércio ilícito, tanto nas ocasiões em que ele foi apreendido, quanto nas que não foi, seja por falta de condições, inoperância ou permissividade da Alfândega, que se somava às estratégias utilizadas pelos comerciantes-contrabandistas, que contavam com a corrupcão de empregados públicos desta repartição para realizar com sucesso o comércio ilícito.

Contudo, mesmo essa larga margem de autonomia tinha limitações impostas pelo poder do Estado. Ao fim e ao cabo havia ali uma repartição que representava o poder central e que, embora ajustada aos interesses locais, fazia-se sentir garantindo que as mercadorias de comércio lícito ou ilícito passassem sob seu controle e taxação (mesmo que subtaxados). Além disso, quando parecia que se havia extrapolado a autonomia aceitável, Comissões de fiscalização eram instaladas para regularizar seu funcionamento. A partir de 1844, são criadas Comissões para fiscalização das arrecadações, escriturações e regularidade dos empregados no exercício de suas funções nas Alfândegas. Foi em função da atuação da primeira Comissão na Alfândega de São Borja, devido às inúmeras irregularidades encontradas, que esta repartição foi suprimida, em 1849, e transferida para Uruguaiana juntamente com a criação das Mesas de Renda de Jaguarão, Itaqui, e São Borja, sendo que as duas últimas ficaram sob jurisdição de Uruguaiana.

Conforme referido, sabe-se que a transferência da sede da Alfândega de São Borja para Uruguaiana não se deu apenas em função das irregularidades encontradas pela Comissão de fiscalização de 1849. Havia uma grande demanda para tal mudança. A transferência para Uruguaiana respondia à necessidade do crescente comércio que por ali se

27. A intensa atividade mercantil da região foi apontada por viajantes como Nicolau Dreys, quando por ali passou, entre 1817 e 1838, e Ave-Lallemant, em 1858. Dreys, Nicolau, Notícia descriptiva da Província do Rio Grande de São Pedro do Sul, Porto Alegre, Instituto Estadual do Livro, 1961, p. 126; Avé-Lallemant, Robert Christian Bertold, Viagem pelo sul do Brasil no ano de 1858, Belo Horizonte, Editora Itatiaia, 1980, p. 236.

28. Algo que denota o incremento do comércio após a Regulamentação de 1852 foi que a livre navegação estimulou iniciativas privadas e incentivos governamentais para o desenvolvimento de transporte de carga e de passageiros. Foi a partir desse momento que enormes Companhias Fluviais começaram a aparecer na Argentina. Ver: Medrano, Lilia Inês Zanotti de. A livre navegação..., cit., p. 221. Da mesma forma, em 1857, vemos a proposta para a instalação do Vapor Uruguai no Rio Uruguai justificada como muito mais eficiente para o comércio e trânsito de pessoas que as embarcações a vela; ela seria realizada por Antonio Rodrigues Chaves Filho, que contava com 10 contos de réis de subvenção do governo para tal empresa. Arquivo Histórico do Rio Grande do Sul (AHRGS). Fazenda. Uruguaiana. Maço 490. s/n. ${ }^{\circ} 1857$. 
formava sem, contudo, dispor de um meio de fiscalização. Nesse sentido, a criação da Alfândega em Uruguaiana deveu-se, não apenas a uma tentativa de coibir o contrabando, mas a uma possibilidade de arrecadação em um lugar onde o comércio desenvolvia-se a passos largos.

Uma vez estabelecida a Alfândega em Uruguaiana, esperava-se, por certo, que a arrecadação dos impostos comerciais se incrementasse. Contudo, é necessário considerar a deficiência técnica enfrentada pela repartição, no sentido de precárias condições de trabalho, o que gerava conseqüências diretas no cumprimento satisfatório de suas atribuições. Nesse sentido, era comum que o quadro de empregados raramente estivesse completo, e a carência de funcionários gerava o acúmulo de funções. Os funcionários atuavam como substitutos, na falta de alguém especificamente nomeado para determinada função, ou como interinos, quando do impedimento de algum funcionário para exercer o cargo.

Se a falta de condições de trabalho pode justificar muito da deficiência da atuação da Alfândega de Uruguaiana, contudo, não pode ser responsabilizada por todo o problema. A não apreensão de contrabandos também se deveu, muitas vezes, à corrupção dos empregados públicos que estabeleciam alianças com grupos de interesse ligados ao comércio. Estes se relacionavam de diferentes formas com a estrutura alfandegária, dependendo do inspetor que estava no comando, mantendo uma estrutura, de certa forma, solidificada de funcionamento entre o comércio local e a estação fiscal, com alguns padrões de procedimento que mantinham protegidos os interesses dos negociantes. O contrabando podia se dar pela passagem de mercadorias por passos de fronteira desguarnecidos, mas também era passível de ser passado por dentro da própria Alfândega, valendo-se de estratégias consolidadas que aparecem permanentemente ao longo das diferentes gestões de inspetores.

Para compreender como esses procedimentos se sedimentaram no funcionamento da repartição é preciso ter em conta que os funcionários da Alfândega de Uruguaiana, desde sua instituição, variaram muito pouco. Eram pessoas, nem sempre naturais do lugar, mas estabelecidas na região em função de serem empregados públicos e de terem se atrelado aos diferentes grupos de interesse existentes. Nesse contexto, a cada novo inspetor que assumia a chefia da Alfândega deveria haver um novo ajuste entre o recém chegado, os empregados que já estavam lá situados e as redes sociais locais.

Há uma constante no sentido de que um Inspetor que pretendesse moralizar efetivamente o funcionamento da fiscalização não conseguiria permanecer por muito tempo no cargo. Mesmo sendo um funcionário que desfrutava de respaldo político, haja vista que os Inspetores de Alfândega eram nomeados pelos altos escalões do poder, por indicação do Ministro da Fazenda e anuência do Presidente da Província e Inspetor Geral, caso resolvesse pelo enfrentamento com os «locais», poderia sofrer diversos tipos de retaliação, ameaças, atentados contra sua vida e/ou ver-se envolvido em processos como os Autos de Responsabilidade. Esses processos corriam, muitas vezes, apenas localmente, não saíam da Comarca, desse modo os Inspetores poderiam ficar enfraquecidos politicamente nessa disputa. 
Considerando que a afirmação de Stuart B. Schwartz ${ }^{29}$ a respeito da incrível habilidade da sociedade colonial para «abrasileirar» os burocratas possa ser colocada para a sociedade imperial, no sentido da capacidade de cooptação de funcionários enviados pelo poder geral pelas redes locais, podemos inferir que a maior parte dos inspetores designados para a Alfândega de Uruguaiana tenham se acomodado nessas redes. Na realidade, tratava-se de uma «mão de duas vias». Se para sua permanência no cargo os inspetores precisavam se atrelar às redes locais, por outro lado, as redes locais também precisavam do respaldo de pessoas que ocupavam determinados postos de poder. Segundo João Fragoso, em sociedades pré-industriais o sucesso dos negócios dependia da «boa vontade» de sujeitos que ocupavam importantes cargos públicos. ${ }^{30}$ Nesse sentido, alianças eficientes deveriam ser polivalentes, atuando em diferentes meios políticos e econômicos, funcionando como um «mecanismo de defesa e coesão do elitismo». ${ }^{31}$

Uma forma, que encontrei, de me aproximar das relações estabelecidas de aceitação, ou não, dos inspetores foi através dos posicionamentos da Câmara de Vereadores em relação a eles. Tomei a Câmara de Vereadores como parâmetro, pela razão óbvia de que ela constitui a representação do poder político do município por excelência, sendo espaços respeitados e disputados, mas, especialmente nesse caso, porque percebi que a Câmara de Vereadores agia como interlocutora dos interesses da praça comercial em muitos casos.

A correspondência da Câmara destinada ao gabinete da presidência da província é um dos meios pelos quais se pode ter acesso ao posicionamento dessa elite política e econômica local, em relação às diferentes inspetorias, à medida que eles expõem suas reclamações, ou bajulações, a respeito dos inspetores para o poder central da província. Ao longo dos Autos de Responsabilidade, outros representantes do poder local, como juizes de paz, juizes municipais, delegados e subdelegados de polícia também se manifestam positiva ou negativamente em relação aos inspetores da Alfândega.

QUADRO 1. Relação de Inspetores da Alfândega de São Borja.

\begin{tabular}{llc}
\hline Nome & \multicolumn{1}{c}{ ENTRADA } & SAÍDA \\
\hline Estanislau José de Freitas & $30 / 09 / 1844$ (nomeação) & - \\
Manoel Joaquim d'Almeida & $\mathrm{xx} / 03 / 1849$ (nomeação) & - \\
José Joaquim Fernandes Pinheiro da Cunha & $\mathrm{xx} / \mathrm{xx} / 1849$ & - \\
(interino) & & $03 / 12 / 1849$ (demitido) \\
Felipe Betbezé d'Oliveira Néri (interino) & $25 / 06 / 1849$ & - \\
José Gomes Ferreira Guimarães Cabeça & $04 / 12 / 1849$ & \\
\hline
\end{tabular}

29. Schwartz, Stuart B, Burocracia e sociedade no Brasil colonial, São Paulo, Perspectiva, 1979.

30. Fragoso, João, «Potentados coloniais e circuitos imperiais: notas sobre uma nobreza da terra, supracapitanias, no Setecentos. Optima Pars - Elites Ibero-Americanas do Antigo Regime, Lisboa, ICS, 2005, p. 146.

31. Dias, Maria Odila Leite da Silva. «A interiorização da metrópole», A interiorização da metrópole e outros estudos, São Paulo, Alameda, 2005, p. 28. 
QUADRO 2. Relação de Inspetores da Alfândega de Uruguaiana entre 1854 e 1864.

\begin{tabular}{|c|c|c|}
\hline Nome & ENTRADA & SAÍDA \\
\hline Thomaz Francisco Flores & $\begin{array}{l}\text { 24/04/1852 (adido) } \\
\text { 13/03/1853 (nomeação) }\end{array}$ & 06/10/1854 (demitido) \\
\hline $\begin{array}{l}\text { Candido Martins dos Santos Vianna Junior } \\
\text { (interino) }\end{array}$ & $\begin{array}{l}\text { 19/08/1854 (nomeação) } \\
\text { 20/01/1855 (assume) }\end{array}$ & $16 / 05 / 1855$ \\
\hline Caetano de Sousa Pinto & $\begin{array}{l}\text { 06/10/1854 (nomeado) } \\
16 / 05 / 1855 \text { (assume) }\end{array}$ & 28/10/1857 (demitido) ${ }^{32}$ \\
\hline $\begin{array}{l}\text { Marcelino Antonio da Silva } \\
\text { Comissão de Rio Grande - Joaquim Manoel } \\
\text { de Azevedo e Abel Pires de Oliveira }{ }^{34}\end{array}$ & $27 / 03 / 1857^{-}$ & $23 / 03 / 01857^{33}$ \\
\hline João Cesário de Abreu (cargo em comissão) & $28 / 10 / 1857$ & $11 / 12 / 1858$ \\
\hline João do Espírito Santo Araújo (substituto) & $11 / 12 / 1858$ & \\
\hline Antonio José Caetano da Silva & $\begin{array}{l}\text { 05/02/1859 (nomeação) } \\
\text { 09/05/1859 (assume) }\end{array}$ & - \\
\hline Eleutério Augusto de Atahyde & $\mathrm{xx} / \mathrm{xx} / 1860$ & $\mathrm{xx} / \mathrm{xx} / 1860$ \\
\hline Herculano Eugenio Sampaio & $\mathrm{xx} / 01 / 1861$ & - \\
\hline Comissão & $15 / 11 / 1861$ & 26/12/1861 \\
\hline Antonio Campos Junior & - & $\mathrm{xx} / 04 / 1863$ \\
\hline João Correa Leães (interino) & $\mathrm{xx} / 04 / 1863$ & $01 / 07 / 1863$ \\
\hline Sebastião Marques de Sousa & 01/07/1863 (nomeação) & - \\
\hline Antonio Tello Barreto Filho & $\begin{array}{l}\text { 27/02/1864 (nomeação) } \\
\text { 03/06/1864 (assume) }\end{array}$ & - \\
\hline
\end{tabular}

Fontes: Barbosa, Eni. O Órgão Fazendário no Rio Grande do Sul (1831-1859), Porto Alegre, PUCRS, 1979, Dissertação de Mestrado, Anexo 13, pp. 334, 335.

AHRGS, Fazenda, Alfândega de Uruguaiana, Maço 490.

Thomaz Francisco Flores foi, efetivamente, o primeiro Inspetor da Alfândega de Uruguaiana. Sua indicação para o cargo, feita pelo Inspetor da Tesouraria da Fazenda, Rafael Arcanjo Galvão, foi justificada em função de sua «luta aberta contra a fraude habitual de lugares tão distantes da Capital aonde parece que apenas havia noticia, mas não se sentirão nunca os effeitos da Legislação Fiscal».

Sua primeira ação, de que se tem conhecimento à frente da Alfândega de Uruguaiana, foi, ainda funcionando como adido, a investigação de «um plano formado entre diversas pessoas», incluindo funcionários da Alfândega, que a través de denúncias falsas de contrabando chantageavam comerciantes para que a denúncia fosse retirada. Para tanto, reuniu declarações de onze comerciantes estabelecidos em Uruguaiana, que teriam sido

32. Data da demissão formal, pois já estava afastado.

33. Data em que pediu o afastamento do cargo.

34. Com o afastamento e pedido de demissão de Marcelino Antonio da Silva, os dois membros da comissão revezaram na inspetoria. Primeiro Joaquim e depois Abel. 
vítimas da armadilha ou que sabiam do ocorrido, e, juntamente com um ofício esclarecendo os fatos, encaminhou a reclamação por punição dos criminosos ao Inspetor da Fazenda para que chegasse ao Presidente da Província, João Lins Vieira Cansansão de Sinimbú. A resposta do Palácio da Presidência veio em um ofício de 27 de abril de 1853 e tratava de responsabilizar o escrivão da Alfândega, Anacleto Nolasco Rodrigues Paz, que estava envolvido no crime..$^{35}$

Rapidamente a Câmara buscou meios de demonstrar sua insatisfação com esse inspetor, que interferia no andamento das questões locais. Em 4 de janeiro de 1853, a Câmara enviou correspondência ao inspetor para reclamar da sua atitude de cobrar impostos sobre a carne fresca e «outras miudezas comestíveis» vindas do outro lado do rio. ${ }^{36}$

Contudo, no dia 18 do mesmo mês, o inspetor respondeu à Câmara justificando o porquê permaneceria cobrando as taxas de importação das «miudezas comestíveis». Segundo ele, a livre passagem desses alimentos (batata, mandioca, milho e queijo) «he o quanto basta para não só matar alguma industria semelhante neste Município, como alimentar nelle a preguiça e a ociosidade (...)». Diante da intransigência do inspetor, a Câmara se fez representar através de ofício encaminhado ao gabinete do Presidente da Província, em 12 de março de 1853, denunciando as indelicadezas de Thomaz Flores de quem dizem «não saber apreciar as localidades e a posição dos lugares» e, dessa forma, vinha interferindo no funcionamento consolidado das coisas: «Não questiona Exmo. Snr esta Câmara se a Lei authoriza ou não a cobrança indicada, estranha tão somente que ella nunca estivesse em uso antes, e que agora este Inspector enverga-se mais que as seus antecessores». ${ }^{37}$

A orientação das atitudes de Thomaz Flores na Alfândega não pareceu ter sido abalada em função da oposição que sofreu por parte do poder local e, dessa forma, empreendeu sua próxima ação sobre um empregado da Alfândega, Antonio Vianna de Andrade, em outubro de $1853 .{ }^{38}$

Antonio Vianna de Andrade era Guarda da Alfândega e, segundo o ofício do Inspetor para o Juiz Municipal Luiz Carlos Magalhães, no dia 1o de outubro de 1853, foi preso em flagrante por ter proferido injúrias, calúnias e feito ameaças ao Inspetor na presença de testemunhas. Além disso, declarou que não reconhecia a Thomaz Francisco Flores como seu superior. Os reveses em decorrência dessa postura aconteceram rapidamente.

Thomaz Francisco Flores foi apontado como réu em um Processo Crime de Tentativa de Homicídio, ${ }^{39}$ em fevereiro de 1854, por ter desferido um tiro em Fernando Viera de Carvalho, escrivão da Alfândega desde 08 de maio de 1850. No decorrer do processo, descobre- se que havia uma premeditação por parte de vários desafetos do inspetor

35. Arquivo Público do Estado do Rio Grande do Sul (APERS), Poder Judiciário. Cível e Crime, Processos Crime. Alegrete - Maço 78, no 2754, ano 1853.

36. Arquivo Histórico do Rio Grande do Sul (AHRGS), Câmara Municipal de Uruguaiana - Correspondência Expedida 1850/1858. A.MU-337 Cx 182. no220.

37. APERS, Poder Judiciário. Cível e Crime, Processos Crime, Alegrete - Maço 78, no 2754, ano 1853.

38. APERS, Poder Judiciário. Cível e Crime, Processos Crime, Uruguaiana - Maço 60, no 2341, ano 1854.

39. APERS, Poder Judiciário. Cível e Crime, Processos Crime, Uruguaiana - Maço 60, no 2338, ano 1854. 
para que uma determinada situação ocorresse e culminasse com o disparo (não mortal, uma vez que o cartucho só estava carregado com pólvora) pelo Inspetor contra o escrivão Fernando, o que possibiliatava a abertura de um processo contra Thomaz. As «perseguições» empreendidas pelo Inspetor ainda renderam mais reações. Em dezembro de 1853, Thomaz recebeu uma ameaça de morte vinda de Salto Oriental que dizia:

Um amigo de voça mercê lhe previne que se ponha em salvo que lhe consta que há um complô tramado para assassinar porque disem que voça mercê he mui de mau coração para com todos e que suas Arbitrariedades não tem termos porque todos os dias está tomando medidas de despotismo e fasendo barbaridades de toda a classe, em fim aqui lhe posso assegurar é que voça mercê vai morrer assassinado mui pompto por vários patrícios que hão vindo dessa lhe hão dito aqui a gritos e sem reserva. ${ }^{40}$

$\mathrm{Na}$ trama dessa rede de alianças e oposições, fica evidente que o problema fundamental foi o fato de Thomaz Francisco Flores ser alguém de fora da paróquia, mas que não representava diretamente os interesses locais e que não quis se enquadrar de todo nos usos do comércio da região. Nesse sentido, na Portaria de Suspensão de Fernando Vieira de Carvalho, um dos motivos apontados pelo Inspetor para esse procedimento é que a insubordinação do Escrivão se deve ao fato de que ele queria ter assumido o cargo de Inspetor quando Thomaz foi nomeado em substituição de José Gomes Ferreira Guimarães Cabeça, que havia sido suspenso. Se tivesse assumido a inspetoria, Fernando Vieira de Carvalho poderia dar seguimento a orientação que a Alfândega vinha tendo sob o comando do inspetor anterior, já que Fernando e Cabeça provavelmente transitavam no mesmo grupo de interesse. Manoel Gomes Guimarães Cabeça, filho de José Gomes Ferreira Guimarães Cabeça, por exemplo, teve um contrabando apreendido no dia $1 .^{\circ}$ de outubro de 1853. Nesse mesmo dia, Antonio Viana de Andrade também havia sido preso por ordem do Inspetor ${ }^{41}$ e apontou o citado Manoel como seu fiador para sair da prisão.

O inspetor acabou absolvido no processo de tentativa de homicídio, no entanto, isso não desanimou seus opositores, pelo contrário, abriu um novo e último capítulo nessa disputa. Exatamente um dia após a sentença final, Thomaz Francisco Flores foi acusado novamente em um Auto de Responsabilidade. ${ }^{42}$

A autoria do processo é da Justiça, através do Promotor Público Manoel Joaquim de Almeida. Esse foi o último processo sofrido por ele, enquanto Inspetor da Alfândega de Uruguaiana, já que foi demitido em 6 de outubro deste mesmo ano. São apontados também como réus nesse processo o empregado da Alfândega José Vicente de Oliveira e o ex-guarda da mesma repartição Antonio Vianna de Andrade. Contudo, suas participações nesse processo foram meramente figurativas já que haviam cumprido ordens dadas pelo Inspetor da Alfândega e por isso não poderiam ser responsabilizados diretamente.

40. APERS, Poder Judiciário, Cível e Crime, Processos Crime, Uruguaiana - Maço 60, no 2338, ano 1854.

41. Consta no processo n. ${ }^{\circ} 2341$ já relatado.

42. APERS, Poder Judiciário, Cível e Crime, Processos Crime, Alegrete - Maço 79, no 2785, ano 1854. 
Baseado no fato de que o Inspetor mantinha um comportamento irascível e, inclusive «pela mais simples causa ameaçava com prizoens», e no fato de que aparentemente mantinha alguns comerciantes como seus protegidos, esse processo estava justificado nos seguintes termos: «O Inspector Thomaz Francisco Flores tem causado graves perdas aos interefses da Fazenda Nacional pondo obstáculos ao commercio licito com grandes entraves, e afsim protegendo o contrabando».

O Promotor baseia a denúncia no fato de que o Inspetor teria mandado prender a vários comerciantes aparentemente sem motivo. De sua parte, o inspetor Flores contesta a acusação e afirma terem sido cabíveis todas as prisões efetuadas, sendo que uma delas lhe rendeu especial tormento e outra ameaça de morte: a prisão de Nicolau Sicardi, o Garibaldi, ou, segundo Thomaz Flores, «o tamanduá da plebe da Uruguayana contra o Inspetor d'Alfandega». Este comerciante estrangeiro foi preso no dia 20 de junho de 1853 , tendo permanecido nessa condição cerca de quatro dias e meio. O motivo era detêlo em repreensão a delitos cometidos anteriormente, averiguar sobre a existência de «uma tal Companhia dos $10 \%$ » e prevenir a efetivação de um plano de contrabando que seria realizado no dia 23 de junho. Os crimes antecedentes que cita são de contrabando. Um deles ocorrido na noite de 7 de janeiro de 1853, composto de 22 volumes de fazendas estrangeiras, de propriedade dos comerciantes Irmãos Monjardim de Uruguaiana, não foi possível de ser apreendido pois que a tripulação do barco de Garibaldi estava armada e em maior número que os guardas da Alfândega. Dias depois, na noite de 28 de janeiro, o Inspetor conseguiu apreender 57 peças de morim contrabandeadas por Garibaldi.

Para o Inspetor, Nicolau Sicardi era um dos agentes mais fortes do contrabando daquela região e mantinha relações com diversos comerciantes daquela praça em especial com os citados Irmãos Monjardim. Nesse sentido, era apontado como o organizador de um grupo que vinha sendo investigado por Thomaz Flores, a chamada «Companhia dos $10 \%$ «em que entram comerciantes, barqueiros e, não há que duvidar, algum empregado desta Alfândega, mediante a retribuição em dinheiro de $10 \%$ do valor das mesmas mercadorias contrabandeadas». No último dia 19, um antes da prisão de Garibaldi, Thomaz Flores foi informado do plano de «um desembarque de contrabando para o dia 23 entre o arroio Imbahá e o porto, favorecido pela distração dos festejos de véspera de São João». Por esses dias também, o Inspetor foi avisado da intenção do comerciante italiano de assassiná-lo. Coincidência ou não, pouco depois foi afixado em sua porta um «pasquim» ameaçando-o. O texto da ameaça é o que segue:

Teus enemigos que são muitos, formão couzas orroros: amigos não tens que te defendão, por que patrícios e estrangeiros não desejão mais que berse libre de V. M. Barrabás.

Deja este poubo em santa paz,

Opressor da umanidade;

Por que o remédio será a

Eternidade, eternidade, eternidade! ${ }^{43}$

43. APERS, Poder Judiciário, Cível e Crime, Processos Crime, Alegrete - Maço 79, no 2785, ano 1854. 
Assim que Nicolau Sicardi foi preso, começaram a reunir-se um grupo de pessoas no porto, pronunciando-se a favor de Garibaldi e contra o Inspetor. Entre eles estavam o subdelegado Cesarino dos Santos Guterres, Francisco José da Cruz, Manoel Dória da Luz, Isidro Brunet, Monjardim, Antonio Soares Leães e José Gomes Guimarães Cabeça. O Inspetor afirma ter sido avisado de que «nessa noute de 20 de junho ia ser atacado em sua própria casa por essa população amotinada». O temor do Inspetor não se dava por pouco, uma vez que havia um antecedente em que a população quis «tomar contas a hua autoridade». Em 1851, o Capitão Fortunato Francisco da Silva, comandante da guarnição da Vila, foi atacado no quartel por um grupo insurgente da população, onde também participaram Francisco José da Cruz e Manoel Dória da Luz, na época juiz municipal, com o intuito de que o capitão libertasse cinco presos.

No entendimento do Promotor Público essas prisões e expulsões da Alfândega, feitas por Thomaz Flores a comerciantes, constituíam os motivos para imputar um processo de responsabilidade ao Inspetor, alegando que, dessa forma, ele havia colocado obstáculos ao comercio licito e, conseqüentemente, favorecido o ilícito.

Thomaz Flores permaneceu suspenso, desde 21 de fevereiro de 1854, em decorrência do processo de Tentativa de Homicídio, e só reassumiu seu cargo na inspetoria em 21 de julho do mesmo ano. Contudo, acabou sendo demitido em 6 de outubro.

A partir da demissão de Thomaz Flores, assumiu interinamente a Inspetoria da Alfândega o escriturário Candido Martins dos Santos Viana Junior. Poucos dias depois, em 14 de outubro de 1854, Caetano de Sousa Pinto foi nomeado o novo Inspetor da Alfândega de Uruguaiana. Ao que tudo indica, o inspetor Caetano de Sousa Pinto manteve um bom relacionamento com as representações locais, pelo menos não sofreu retaliações através da instauração de Autos de Responsabilidade como seu antecessor. É possível arriscar que o motivo para o Inspetor Caetano ter cumprido dois anos no cargo sem esse tipo de incômodo deva-se ao seu ajuste às praticas do comércio da fronteira oeste. Nesse sentido, ao contrário de Thomaz Francisco Flores, que era destratado nos ofícios que a Câmara de Vereadores encaminhava ao poder provincial, Caetano desfrutava de boa aceitação.

Em um ofício, de 27 de maio de 1857, encaminhado ao Presidente da Província para reclamar da Comissão que seria instalada ali posteriormente para fiscalizar os procedimentos da Alfândega de Uruguaiana, os vereadores se manifestaram em relação a Caetano em um tom de pesar pelo seu afastamento:

Veio porém administrar essa Alfândega o honrado e intelligente empregado Caetano de Souza Pinto, que estabelecendo ordem na administração da Alfândega, facilitando os despachos e sobre tudo, sua urbanidade, moderação e probidade attrahindo as simpathias do commercio, chamouo a Alfândega e se não conseguio extinguir de todo o contrabando o que é mesmo impossível, elle tornou-se insensível e inteiramente reprovado. Então esta Villa e seu Commercio principiou a prosperar, e a definhar a Povoação em frente, crescendo rapidamente as Rendas da Alfândega; retirou-se porem esse Snr. deixando Geral pezar em todos commerciantes e particulares(...).44

44. AHRGS - Câmara Municipal de Uruguaiana - Correspondência Expedida 1850/1858, A.MU-337 Cx 182. no 272 . 
Não se trata de duvidar de que os rendimentos da Alfândega tenham realmente aumentado no período do inspetor Caetano; contudo, considerando que são os mesmos comerciantes regulares os que empreendem o contrabando, e que boa parte do comércio ilícito passa por dentro da própria Alfândega, então, se o comércio e a arrecadação da Alfândega crescem, o contrabando deve crescer nas mesmas proporções. Sendo assim, fica esclarecido porque que Caetano teria caído «nas graças» dos fronteiriços.

No mesmo sentido, em relação a Marcelino Antonio da Silva, empregado da Alfândega que sucedeu Caetano na inspetoria, a Câmara também se refere com boas lembranças: «(...) havendo lhe [refere-se a Caetano de Sousa Pinto] succedido o honrado Snr Capitão Marcellino Antonio da Silva sob cuja administração continuou o crescimento nas rendas da Alfândega, e a prosperidade desta localidade».

Não é possível precisar quando e porque Caetano se afastou, ou foi afastado, da Inspetoria. A data de sua demissão formal, em 28 de outubro de $1857,{ }^{45}$ foi muito depois do seu afastamento, e, enquanto isso, Marcelino ficou a frente da repartição até 23 de março de 1857. Em 27 de março de 1857, chegou em Uruguaiana uma Comissão de fiscalização composta por dois funcionários de Rio Grande, Joaquim Manoel de Azevedo e Abel Pires de Oliveira, para coordenar e investigar esta Alfândega.

A Comissão havia sido designada através de portaria, de 28 de fevereiro, da Tesouraria da Fazenda para examinar os despachos feitos na Alfândega de Uruguaiana. Segundo o oficio do chefe da Comissão ao Inspetor da Fazenda, a Alfândega de Uruguaiana tinha se tornado «huma veradeira casa de comercio, onde os negociantes ajustavão com o chefe e o Feitor Conferente o preço por que devião pagar suas facturas».

A atuação da Comissão, cotejada com as manifestações da Câmara de Vereadores em relação a ela, deixa transparecer que sua intenção era a de, mais uma vez, tentar implementar uma cobrança efetiva das taxas de comércio pela Alfândega de Uruguaiana. O aborrecimento causado pela Comissão é comparado repetidas vezes aos que foram causados ao comércio local no tempo do inspetor Flores, o que pode sugerir que ambos períodos foram marcados pela atuação de pessoas a frente da Alfândega, que não se harmonizaram com os procedimentos do local.

Em 27 de maio de 1857, os vereadores apresentaram os problemas enfrentados pelo comércio fronteiriço e seu profundo descontentamento, senão desespero, com a atuação da Comissão, através de um ofício encaminhado à presidência da província.

Ilmo Exmo. Snr. A Câmara Municipal desta Villa solicita em levar ao conhecimento de V. Ex. ${ }^{a}$ todos os malles do seo Município que demandão remédio, não pode deixar de reprezentar com todo o respeito contra o procedimento da Commissão que pela Thesouraria da Província foi mandada por examinar a administrar a Alfândega desta Villa pelos grandes males de que já se recente esta Povoação, e toda a Fronteira. (.....$^{46}$

45. Barbosa, Eni, O Órgão Fazendário..., cit., p. 335.

46. AHRGS - Câmara Municipal de Uruguaiana - Correspondência Expedida 1850/1858. A.MU-337 Cx 182. n. ${ }^{\circ} 272$. 
A resposta vinda da Presidência da Província, em 18 de junho, respaldou a atuação da Comissão e julgou que a Câmara de Vereadores excedeu suas funções ao interferir em assuntos fiscais. Vendo que sua reclamação junto ao presidente da província não surtiu efeito, prontamente a Câmara insistiu no mesmo procedimento e contestou em 10 de julho:

Ilmo Exmo Snr. A Câmara Municipal desta Villa tendo recebido o officio que V. Ex. ${ }^{a}$ foi servido dirigir lhe com data de 18 passado sob n. ${ }^{\circ} 6$ em resposta a representação que derigio a V.Ex. ${ }^{a}$ em officio de 27 de maio deliberou trazer ainda com todo o respeito as seguintes considerações. Prezenciando esta Câmara as continuadas queixas do Commercio e do povo contra administração da Commissão mandada pela Thesouraria para administrar a Alfândega desta Villa, e tendo perfeito conhecimento que o procedimento dessa Comissão anima e põem em voga o pernicioso Commercio de contrabando aniquilando o Commercio licito; e que este proceder da Comissão e os boatos seguramente infundados, porem que o procedimento da Commisão tem tornado em crença popular faria julgarem uma necessidade a prestarem toda a proteção ao ilícito contrabando; tendo plena certeza destes factos, entendeo, que pelas dispozições do art. ${ }^{\circ} 71$ e 72 da Constiuição do Império e do art. ${ }^{\circ}$ 1. ${ }^{\circ}$ da Lei de 12 de agosto de 1834 era de seu rigoroso dever levar tudo do conhecimento de V. Ex. ${ }^{a}$. (...) A Commissão que em vez de fiscalizar hoje administra despoticamente a Alfândega ainda não encontrando parte desta Câmara o menor óbice as suas medidas mesmo ilegaes. Pode esta Câmara estar em erro porem entende, que representar a Autoridade superior acerca de um mal de perniciosa conseqüência para seu Município, posto que derive da má administração da Alfândega, não é ingerir-se em dita administração. E permitirá $\mathrm{V}$ ex. ${ }^{a}$ de ainda fazer a respeito as seguintes ponderações: Tendo esta Câmara julgado do seo dever levar ao conhecimento de V. Ex. ${ }^{a}$ os acontecimentos momentosos, que se tem dado neste Município e em todo o commercio do Uruguay, com a completa e rápida inversão que estabeleceo a Commissão que veio administrar a Alfândega teve de historiar os factos occoridos afim de que V. Ex. ${ }^{a}$ pudesse bem apreciar a natureza e origem dos males que soffremos: procurou unicamente os consignar com verdade, fundando-se na notoriedade publica. Só quis demonstrar o que é patente isto é 1. ${ }^{\circ}$ que a administração da Alfândega anterior a do Snr. Sousa Pinto, fez definhar o commercio desta Villa, tornando-se a Povoação em frente a esta, na província de Corrientes, o emporio do commercio do Uruguay e vulgar o contrabando, que todos os dias tomava maior vulto zombando das medidas fiscaes, e mesma das violências praticadas pelo então administrador da Alfândega. 2. que com a administração do Snr Sousa Pinto, quase que se extinguiu o contrabando florecendo o Commercio d'esta Villa, tornando-se o deposito do Uruguay e crescerão consideravelmente as rendas d Alfândega. 3. ${ }^{\circ}$ que com a inversão que estabeleceo ultimamente a Commissão, que de fiscalizadora passou a ser administradora estagnou-se o Commercio desta Villa, com notável detrimento mesmo para as rendas Municipaes tornou-se o Povo em frente outra vez o empório do commercio do Uruguay, e o contrabando toma amplas proporções. (...) Cumpre mais a esta Câmara notar que tendo sido essa Commissão nomeada para fiscalizar esta Alfândega, desde que encumbio-se de sua administração perdeo o caráter de fiscalizadora da administração, porque, por que seria irrizoria a fiscalização que farião a seus próprios actos, havendo portanto a urgente necessidade de ser a seu turno fiscalizada. Finalmente esta Câmara pensando unicamente cumprir com seu dever attendendo a magnitude do negocio, e para que a todo tempo seus munícipes não tenhão o direito de ataxarem de indiferente, é que pela ulti- 
ma vez ainda ocupa a attenção de V. Ex. ${ }^{a}$ com estes negocios esperando que desculpará seos erros se sem querer tem excedido de sua atribuições. ${ }^{47}$

O descontentamento com a administração da Comissão era absoluto, e tão pouco teve repercussão junto ao poder provincial, haja vista que a Alfândega de Uruguaiana permaneceu ainda por algum tempo nessa condição. No período em que vigorou a gestão da Comissão na Alfândega, passaram vários inspetores que não necessariamente estavam designados para esta função e, muitas vezes, exerceram o cargo por falta de outra pessoa que o fizesse, ocorrendo freqüentemente o acúmulo de cargos por parte dos membros da Comissão. Ocorreu a nomeação de João Cesário de Abreu para o cargo de Inspetor em comissão em 28 de outubro de 1857, que permaneceu até sua exoneração em 11 de dezembro de $1858,{ }^{48}$ sendo que, nesse mesmo dia, assumiu em substituição João do Espírito Santo Araújo, cuja data de saída não se sabe.

O período da Comissão se conclui quando foi nomeado, em 5 de fevereiro de 1859, o inspetor Antonio José Caetano da Silva, que assumiu o cargo em nove de maio deste ano. Novamente a Alfândega de Uruguaiana dispunha de um inspetor efetivamente designado para aquele cargo depois de dois anos sob o comando de inspetores improvisados durante a vigência da Comissão. Teve início, outra vez, um período de grande estabilidade, no que se refere à manutenção das lógicas comerciais locais, e instabilidade, no sentido de sucessivos inspetores apontados, por grupos de interesse não beneficiados, como envolvidos em práticas de corrupção em função do contrabando.

Isso posto, a relação do contrabando e do papel desempenhado pela Alfandega deixam em evidência a ação e os limites do Estado. Essa vida comercial intensa, fosse ela lícita ou ilícita, tornava indispensável a existência de uma Alfândega nesse local, sobretudo, porque as Alfândegas eram as maiores estações fiscais em termos de arrecadação, e o Império não podia desdenhar dessa possibilidade de incrementar sua receita. ${ }^{49}$ Dessa maneira, a Alfândega existia nesse confim de território e os inspetores que a chefiaram eram homens de fora, nomeados pelo poder provincial ou imperial que precisavam atuar entre a boa convivência com os comerciantes locais e a justificação de sua existência legítima e pertinente naquelas paragens perante o poder central. Uma alfândega que não

47. AHRGS - Câmara Municipal de Uruguaiana - Correspondência Expedida, 1850/1858, A.MU-337 Cx 182, n. $^{\circ} 276$.

48. Também exerceu as funções de: $3 .^{\circ}$ Escriturário da Tesouraria da Fazenda (nomeado em 20/09/1845), 3. ${ }^{\circ}$ Escriturário da Contadoria da Fazenda (nomeado em 03/10/1845), 2. ${ }^{\circ}$ Escriturário da Contadoria da Fazenda (nomeado em 27/07/1849), 2. ${ }^{\circ}$ Escriturário da Tesouraria da Fazenda (nomeado em 06/12/1851) e 1. ${ }^{\circ}$ Escriturário da Tesouraria da Fazenda (nomeado em 27/09/1854). Barbosa, Eni, O Órgão Fazendário..., cit. Anexо 13.

49. Segundo José M. de Carvalho, a cobrança de impostos de importação e exportação era o que de fato alimentava os cofres imperiais e, apesar de muitas discussões políticas para suspendê-los e, assim, dinamizar o comércio, constituíam-se na forma mais fácil e eficiente de arrecadação devido à falta de agentes para a cobrança de outros tipos de taxação (como a per capita ou imposto territorial rural) e porque os «resultados eram imediatos e o contribuinte não percebia que estava pagando». Carvalho, José Murilo de, A construção da ordem: teatro de sombras, Rio de Janeiro, Civilização Brasileira, 2003, p. 269. 
arrecadasse não tinha razão de existir, de ser mantida em funcionamento. Por outro lado, uma alfândega de funcionamento totalmente rígido e íntegro tampouco garantiria sobrevivência e um bom convívio local. Dessa forma, a Alfandega de Uruguaiana estabeleceu um modus operandi que acomodava diversos interesses: o contrabando devia passar por dentro da própria alfandega pagando um valor de imposto que, embora ficasse muito aquém do valor referente ao carregamento real, garantia alguma arrecadação validando a função da repartição fiscal naquele lugar. O corolário dessa conjuntura era o fato de que se o comércio lícito crescia o contrabando também crescia. Um inspetor que coibisse as irregularidades na Alfândega dificultando os despachos de mercadorias, além de sofrer uma série de hostilidades, acabava contribuindo para o crescimento do contrabando «tradicional», já que impossibilitados de fazê-lo por dentro da Alfândega, os comerciantes viam-se obrigados a contrabandear pela fronteira desguarnecida, na calada da noite, munidos de bandos armados para escoltar as mercadorias. Ainda assim, pode-se reforçar que a licença desfrutada pela Alfândega de Uruguaiana sofreu contenções quando o Estado julgou que o grau de autonomia daquela repartição pública havia extrapolado a transgressão consentida. A Alfândega de Uruguaiana sofreu pelo menos três vezes a instalação de Comissões de fiscalização cujo objetivo era avaliar a probidade dos procedimentos dos funcionários daquela repartição, uma em 1849, quando da transferência de São Borja para Uruguaiana, a segunda em 1857 e outra em $1861 .^{50}$ Nenhuma delas foi bem recebida pela comunidade de comerciantes conforme discussões travadas nas correspondências da Câmara Municipal endereçadas ao Presidente da Província.

Portanto, independente de como chegava a ação do estado nas suas bordas territoriais, ela não é desprezível ou inexistente e desempenha funções concretas no cotidiano desse contexto fronteiriço.

\section{Fontes primárias impressas}

Dreys, Nicolau. Notícia descriptiva da Província do Rio Grande de São Pedro do Sul. Porto Alegre, Instituto Estadual do Livro, 1961.

Avé-Lallemant, Robert Christian Bertold. Viagem pelo sul do Brasil no ano de 1858. Belo Horizonte, Editora Itatiaia, 1980.

\section{Fontes primárias manuscritas}

Arquivo Histórico do Rio Grande do Sul (AHRGS).

AHRGS. Fazenda. Uruguaiana. Maço 490. s/n. ${ }^{\circ} 1857$.

50. APERS, Poder Judiciário, Cível e Crime, Processos Crime, Uruguaiana, Maço 62, n. ${ }^{\circ}$ 2402, ano 1857. APERS, Poder Judiciário, Cível e Crime, Processos Crime, Uruguaiana, Maço 64, n. ${ }^{\circ}$ 2470, 1862. Relatório da Comissão de Inspeção da Alfândega de Uruguaiana de 1861. 
AHRGS. Câmara Municipal de Uruguaiana - Correspondência Expedida 1850/1858. A.MU-337 Cx 182. no220.

AHRGS - Câmara Municipal de Uruguaiana - Correspondência Expedida 1850/1858. A.MU-337 Cx 182. no272.

AHRGS - Câmara Municipal de Uruguaiana - Correspondência Expedida 1850/1858. A.MU-337 Cx 182. n. ${ }^{2} 276$.

Arquivo Público do Rio Grande do Sul (APERS).

PERS. Poder Judiciário, Cível e Crime, Processos Crime, Alegrete - Maço 78, no 2754, ano 1853. APERS. Poder Judiciário, Cível e Crime, Processos Crime, Alegrete - Maço 79, no 2785, ano 1854. APERS. Poder Judiciário, Cível e Crime, Processos Crime. Uruguaiana - Maço 60, no 2338, ano 1854.

APERS. Poder Judiciário, Cível e Crime, Processos Crime. Uruguaiana - Maço 60, no 2341, ano 1854.

APERS. Poder Judiciário, Cível e Crime, Processos Crime, Uruguaiana, Maço 62, n. ${ }^{\circ}$ 2402, ano 1857.

APERS. Poder Judiciário, Cível e Crime, Processos Crime, Uruguaiana, Maço 64, n. ${ }^{\circ}$ 2470, 1862. Relatório da Comissão de Inspeção da Alfândega de Uruguaiana de 1861.

\section{Bibliografia}

Barbosa, Eni, O Órgão Fazendário no Rio Grande do Sul (1831-1859), Dissertação de Mestrado, Porto Alegre, PUCRS, 1979.

Braddick, Michael J., «Fiscal transformation and political compliance: England, 1550-1700», Illes i Imperis. Estudis d'història de les societats en el món colonial i postcolonial, núm. 13, 2010, pp. 21-37.

Brewer, John, The sinews of Power. War, Money and English State, 1668-1783, London, Routledge, 1994 [1ed. 1989].

Carvalho, José Murilo de, A construção da ordem: teatro de sombras, Rio de Janeiro, Civilização Brasileira, 2003.

Costa, Wilma Peres, «Do domínio à nação: os impasses da fiscalidade no processo de Independência», Jancsó, István (ed.), Brasil: formação do estado e da nação. São Paulo, HUCITEC, 1996, 2003.

_-, «A Independência na historiografia brasileira». en Jancsó, István (ed.), Independência: bistória e historiografia. São Paulo: Hucitec/FAPESP, 2005.

_-, «A fiscalidade e seu avesso: centro e províncias na constituição da estrutura fiscal brasileira na primeira metade do século XIX», Chaves, Cláudia M. das G. e Marco A. Silveira, Território, conflito e identidade. Belo Horizonte, Argvmentvum, Brasília, CAPES, 2007, pp. 127-148.

Costa, Wilma Peres e Márcia Eckert Miranda, «Entre os senhores e o Império: transformações fiscais na formação do Estado brasileiro, 1808-1840», Illes i Imperis. Estudis d'història de les societats en el món colonial i postcolonial. núm.13, 2010, pp. 87-115.

Delgado Ribas, Josep M., «Construir el Estado, destruir la Nación. Las reformas fiscales de los primeros Borbones e el colapso del sistema de equilibrios en el Imperio español (1714-1796)», 
Illes i Imperis. Estudis d'bistòria de les societats en el món colonial i postcolonial, núm. 13, 2010, pp. 63-85.

Dias, Maria Odila Leite da Silva, «A interiorização da metrópole», A interiorização da metrópole e outros estudos. São Paulo, Alameda, 2005.

Figueiredo, Luciano Raposo de Almeida. Revoltas, fiscalidade e identidade colonial na América portuguesa - Rio de Janeiro, Babia e Minas Gerais, 1540-1761. Faculdade de Filosofia, Letras e Ciências Humanas, Universidade de São Paulo, São Paulo, 1996, Tese de Doutorado.

Fradera, Josep Maria, «Presentación», Illes $i$ Imperis. Estudis d'història de les societats en el món colonial i postcolonial, núm. 13, 2010, pp. 9-19.

Fragoso, João. «Potentados coloniais e circuitos imperiais: notas sobre uma nobreza da terra, supracapitanias, no Setecentos», Optima Pars - Elites Ibero-Americanas do Antigo Regime, Lisboa, ICS, 2005.

Garavaglia, Juan Carlos, Poder, conflicto y relaciones sociales: el Rio de la Plata, XVIII - XIX. Rosario, Homo Sapiens Ediciones, 1999.

Garavaglia, Juan Carlos, «Algunos aspectos preliminares acerca de la «transición fiscal», en America Latina, 1800-1850», Illes i Imperis. Estudis d'història de les societats en el món colonial i postcolonial, núm. 13, 2010, pp. 159-192.

Halperín Donghi, Tulio, Guerra y finanzas en los orígenes del Estado Argentino (1791-1850), Buenos Aires, Prometeo Libros, 2005. [1ed. 1982].

Martins, Rui Cunha, O método da fronteira: radiografia bistórica de um dispositivo contemporâneo (matrizes ibéricas e americanas), Coimbra, Edições Almedina, 2008.

Maxwell, Kenneth R. A devassa da devassa: a Inconfidência Mineira: Brasil - Portugal - 1750-1808, 2. ed. Rio de Janeiro, Paz e Terra, 1978.

Medrano, Lília Inês Zanotti de, A livre navegação dos Rios Paraná e Uruguay: uma análise do comércio entre o Império Brasileiro e a Argentina (1852-1889), Tese de Doutorado - USP, São Paulo, 1989.

Miranda, Márcia Eckert, A estalagem e o Império: crise do Antigo Regime, fiscalidade e fronteira na Província de São Pedro (1808-1831), Campinas-UNICAMP, 2006, Tese de Doutorado.

Miranda, Márcia Eckert, «Fiscalidade e Guerra: o Rio Grande do Sul e o Brasil na Guerra Cisplatina», Anais do IX Encontro Estadual de História. Vestígios do Passado: a História e suas fontes, ANPUHRS, 2008.

Moutoukias, Zacarias, Contrabando y control colonial en el siglo XVII: Buenos Aires, el Atlántico y el espacio peruano, Buenos Aires, Centro Editor de América Latina, 1987.

Schumpeter, Joseph, «The crises of the tax state», International Economic Papers. N.4, New York, Macmillan, 1954.

Schwartz, Stuart B, Burocracia e sociedade no Brasil colonial, São Paulo, Perspectiva, 1979.

Thomposn Flores, Mariana F. da C., Crimes de fronteira: a criminalidade na fronteira meridional do Brasil (1845-1889), Porto Alegre, EdiPUCRS, 2014.

Tilly, Charles, «Reflections on the history of European state-making», Tilly, Charles (ed.), The formation of national states in Western Europe. Princeton: Princeton University Press, 1975.

Tilly, Charles, Coerção, capital e Estados europeus, São Paulo, EDUSP, 1996. 